Sains Malaysiana 49(11)(2020): 2679-2687

http://dx.doi.org/10.17576/jsm-2020-4911-07

\title{
Thermal Behavior of Cocrystal: A Case Study of Ketoprofen-Malonic Acid and Ketoprofen-Nicotinamide Cocrystals
}

(Kelakuan Termal Kokristal: Kajian Kes Kokristal Ketoprofen-Asid Malonik dan Ketoprofen-Nikotinamida)

\author{
Yudi WiCAKSONO*, Dwi Setyawan, ARi Satia Nugraha \& SisWandono
}

\begin{abstract}
Thermal properties are essential parameters in transformations of solid state. It is useful for estimating physicalchemical interactions that occur specifically in a multicomponent system as cocrystal. However, there is still minimum information about determining the thermal properties of cocrystal in literature. In this study, the investigation of thermal behavior of cocrystal was determined in non-isothermal conditions based on the Kissinger method. The ketoprofen-malonic acid (KMA) and ketoprofen-nicotinamide (KN) cocrystal used as model were prepared using solvent evaporation method, while the characterization was performed by powder x-ray diffraction (PXRD), differential scanning calorimetry (DSC), and Fourier-transform infrared (FTIR). From the experimental results, the activation energy ( $E_{d}$ ) of pure ketoprofen, KMA cocrystal, and KN cocrystal are 264.38, 384.77, and $116.64 \mathrm{~kJ} \mathrm{~mol}^{-1}$, while the enthalpy of activation $\left(\Delta \mathrm{H}^{*}\right)$ are $261.31,381.78$, and $113.76 \mathrm{~kJ} \mathrm{~mol}^{-1}$, respectively. The calculated values of entropy of activation $\left(\Delta \mathrm{S}^{*}\right)$ for pure ketoprofen, $K M A$ cocrystal, and $K N$ cocrystal are 465.22, 809.77, and $84.34 \mathrm{~J} \mathrm{~K}^{-1} \mathrm{~mol}^{-1}$ and the free energy of activation $\left(\Delta \mathrm{G}^{*}\right)$ of pure ketoprofen, KMA cocrystal, and KN cocrystal obtained by general thermodynamic equation are $89.53,90.87$, and $84.62 \mathrm{~kJ} \mathrm{~mol}^{-1}$, respectively. Experimental results of the thermodynamic parameters showed cocrystals to have a positive value of $\Delta \mathrm{S}^{*}$, indicating the formation of cocrystals was a nonspontaneous process. Also, the KMA cocrystal had greater free energy of activation $\left(\Delta \mathrm{G}^{*}\right)$ than the KN cocrystal which indicated the formation of the crystal lattice involving greater binding energy than KN cocrystal.
\end{abstract}

Keywords: Cocrystal; ketoprofen; Kissinger method; thermal properties

\section{ABSTRAK}

Sifat terma adalah parameter penting dalam transformasi keadaan pepejal. Ia berguna untuk menganggar interaksi fizikal-kimia yang berlaku secara khusus dalam sistem multikomponen sebagai kokristal. Walau bagaimanapun, maklumat berkenaan penentuan sifat terma kokristal dalam kajian kepustakaan masih kurang. Dalam penyelidikan ini, kajian terhadap sifat terma kokristal ditentukan dalam keadaan bukan isotermal berdasarkan kaedah Kissinger. Ketoprofen-asid malonik (KMA) dan ketoprofen-nikotinamida (KN) yang digunakan sebagai model disediakan menggunakan kaedah penyejatan pelarut, sementara pencirian dilakukan dengan pembelauan sinar-x serbuk (PXRD), kalorimetri pengimbasan pembezaan (DSC) dan transformasi Fourier inframerah (FTIR). Daripada keputusan kajian, tenaga pengaktifan $(E)$ ketoprofen tulen, kokristal KMA, dan kokristal KN adalah 264.38, 384.77 dan $116.64 \mathrm{~kJ} \mathrm{~mol}^{-1}$, sementara entalpi pengaktifan $\left(\Delta \mathrm{H}^{*}\right)$ masing-masing adalah 261.31, 381.78 dan $113.76 \mathrm{~kJ} \mathrm{~mol}^{-1}$. Nilai pengiraan entropi pengaktifan $\left(\Delta \mathrm{S}^{*}\right)$ untuk ketoprofen tulen, kokristal KMA dan kokristal KN adalah 465.22, 809.77 dan 84.34 $J K^{-1} \mathrm{~mol}^{-1}$ dan tenaga pengaktifan bebas $\left(\Delta \mathrm{G}^{*}\right)$ ketoprofen tulen, kokristal KMA dan kokristal KN yang diperoleh oleh persamaan termodinamik am masing-masing adalah 89.53, 90.87 dan $84.62 \mathrm{~kJ} \mathrm{~mol}^{-1}$. Hasil uji kaji parameter termodinamik menunjukkan kokristal yang terbentuk mempunyai nilai $\Delta \mathrm{S} *$ yang positif, menunjukkan pembentukan kokristal tersebut adalah melalui proses yang tidak spontan. Selain itu, kokristal KMA juga mempunyai tenaga pengaktifan bebas $\left(\Delta \mathrm{G}^{*}\right)$ yang lebih besar daripada kokristal KN yang menunjukkan pembentukan kisi kristal kokristal KMA menggunakan tenaga pengikatan yang lebih besar daripada kokristal KN.

Kata kunci: Kaedah Kissinger; ketoprofen; kokristal; sifat terma

\section{INTRODUCTION}

Current research interest in the field of pharmaceutics is to improve the performance of active pharmaceutical ingredient in which the studies aim to gain several improvements, including better pharmaceutical, physiochemical, and biological properties (Pindelska et al. 2017). Thermal properties are parameters that is useful for estimating 
physical-chemical transformations of solid state such as formation processes, polymorphic transformation, and decomposition (Liu et al. 2013). It can also be used to describe the strength of the interaction of components in the crystal lattice, stability, and predict the relative solubility (Tita et al. 2010). Thus, thermal properties are essential information that can be used as a basis for improving the physicochemical properties of the active pharmaceutical ingredient (Tita et al. 2011).

Cocrystal is a multicomponent system of two or more compounds in a stoichiometric form through noncovalent interactions (Pindelska et al. 2017). It can improve physicochemical characters of active pharmaceutical ingredient (solubility, dissolution rate, bioavailability, stability, hygroscopicity, and compressibility) without molecular structure and pharmacological activity alteration (Chadha et al. 2014; Chow et al. 2012; Diniz et al. 2018; Evora et al. 2014; Goud et al. 2012; Liu et al. 2012; Masuda et al. 2012; Sowa et al. 2014; Wang et al. 2015; Yuliandra et al. 2018). In addition, cocrystal is thermodynamically stable for subsequent processes and a better strategy than solid dispersion for an effective dissolution (Teoh et al. 2020). However, information regarding its kinetic parameters related to the thermal behavior of cocrystal is limited.

The purpose of this study was to evaluate thermal behavior of cocrystal through ketoprofen-malonic acid (KMA) and ketoprofen-nicotinamide $(\mathrm{KN})$ cocrystal as the model. Ketoprofen is a non-steroidal anti-inflammatory drug to treat rheumatoid arthritis and osteoarthritis (Shohin et al. 2012). Ketoprofen forms cocrystal with various types of coformers which provide opportunities for performance enhancement (Perpetuo et al. 2017; Vaghela et al. 2014; Wicaksono et al. 2017). Preparation of cocrystals was carried out using solvent evaporation method (Wicaksono et al. 2018, 2017) and differential scanning calorimetry (DSC) was employed to determine kinetic parameters with the Kissinger method.

\section{Materials AND Methods}

\section{SAMPLE PREPARATION}

The KMA and KN cocrystals were prepared by the solvent evaporation method using the procedure described in the literature (Wicaksono et al. 2018, 2017).

\section{CHARACTERIZATION OF COCRYSTAL POWDER X-RAY DIFFRACTION}

The PXRD of cocrystals was examined using a PANalytical X'Pert PRO X-ray diffractometer (Philips) using $\mathrm{Cu} \mathrm{Ka}$ radiation at $1.5406 \AA$. The samples were analyzed at $5-50^{\circ}$ in $2 \theta$ with a step time of $10 \mathrm{~s}$ and a step size of $0.017^{\circ}$. The divergence slit and anti-scattering slit were set at $0.25^{\circ}$ with diffraction experiment on the 10 mm sample size.

\section{FOURIER-TRANSFORM INFRARED}

The infrared spectra of samples were evaluated by an FTIR spectrometer (Bruker Alpha FTIR spectrometer). The measurements were performed over a range of 4000-400 $\mathrm{cm}^{-1}$ with a resolution of $4 \mathrm{~cm}^{-1}$.

\section{DIFFERENTIAL SCANNING CALORIMETRY}

The samples of pure ketoprofen, KMA cocrystal, and $\mathrm{KN}$ cocrystal were examined with a differential scanning calorimeter (Rigaku DSC 8230). The temperature and heat flow accuracy of DSC was calibrated using high purity indium standard. The samples $(2.0 \mathrm{mg})$ were accurately weighed in a hermetically aluminum pan and then sealed. The DSC scanning was performed over the range of $30-200{ }^{\circ} \mathrm{C}$ at a heating rate of $10{ }^{\circ} \mathrm{C} / \mathrm{min}$ under a dry nitrogen atmosphere (flow rate $50 \mathrm{~mL} / \mathrm{min}$ ).

\section{THERMAL PROPERTIES ANALYSIS}

The thermal properties of samples were analyzed by DSC. Temperature and heat flow of the DSC instrument was calibrated using high purity indium standard prior used to measurement. The weight of the sample is around 2.0 $\mathrm{mg}$ inserted in a hermetically aluminum pan. The DSC curves were collected by scanning at different heating rates of 15,20 , and $25^{\circ} \mathrm{C} \mathrm{min}{ }^{-1}$. Measurements were performed in the temperature range of $30-150{ }^{\circ} \mathrm{C}$ under a dry nitrogen atmosphere with a flow rate of $50 \mathrm{~mL} / \mathrm{min}$.

\section{ANALYSIS OF KINETIC PARAMETERS OF THERMAL PROPERTIES}

The DSC curves from multiple scanning at the different heating rate were used to analyze kinetic parameters. The study was carried out in non-isothermal conditions with the Kissinger method using equation (Boonchom \& Danvirutai 2009; Ma et al. 2012; Srivastava et al. 2017; Yang et al. 2016):

$$
\ln \left(\frac{\beta}{T_{\mathrm{P}}^{2}}\right)=\ln \left(\frac{A R}{E_{\mathrm{a}}}\right)-\frac{E_{\mathrm{a}}}{R T_{\mathrm{P}}}
$$

where $\beta$ and $T_{p}$ are the heating rate (Kelvin degrees per minute) and peak temperature (Kelvin degrees), respectively. $A$ is a pre-exponential factor; $R$ is gas constant; and $E_{a}$ is the apparent activation energy. Plotting $\ln \left(\beta / \mathrm{T}_{p}^{2}\right)$ against $1 / T_{p}$ is obtained a straight line, and the activation energy $\left(E_{a}\right)$ is calculated from the slopes of the linear fits as $-E_{a} / R$. 


\section{CALCULATION OF THERMODYNAMIC PARAMETERS}

The general expression of activated complex theory (transition state) is expressed as (Boonchom \& Danvirutai 2009):

$$
A=\left(\frac{e \chi k_{B} T_{p}}{h}\right) \exp \left(\frac{\Delta S^{*}}{R}\right)
$$

where $A$ is a pre-exponential factor of the Kissinger method, $e=2.7183$ is the Neper number; $\chi$ transition factor (unity for monomolecular reactions); $k_{B}$ Boltzmann constant; $h=$ Planck constant; $T_{p}$ the peak temperature of DSC curve; $R=$ gas constant, and $\Delta S^{*}$ is the change of the entropy. Thus, the change of the entropy $\left(\Delta S^{*}\right)$ can be calculated by equation (Boonchom \& Danvirutai 2009; Qi et al. 2014):

$$
\left.\Delta S^{*}=R\left(\ln (A)+\ln h / k T_{p}\right)-1\right)
$$

while

$$
\Delta H^{*}=E_{a}-R T
$$

where $\Delta H^{*}$ is the enthalpy activation and $E_{a}$ is the apparent activation energy, then the free energy of activation $\left(\Delta \mathrm{G}^{*}\right)$ can be determined by the general thermodynamic equation:

$$
\Delta G^{*}=\Delta H^{*}-T \Delta S^{*}
$$

\section{RESULTS AND DISCUSSION}

THE FORMATION OF COCRYSTAL

The PXRD diffractogram, DSC curve, and FTIR spectra of pure ketoprofen, KMA cocrystal, and KN cocrystal were described in Figures 1-3, respectively. The KMA cocrystal has a PXRD diffractogram with specific peaks of $2 \theta$ at
$6.3,13.0,14.2$, and $22.6^{\circ}$, while the $\mathrm{KN}$ cocrystal has specific peaks of $2 \theta$ at $6.4,14.5,18.5,23.0$, and $27.3^{\circ}$. The pure ketoprofen has a DSC curve with an endothermic peak at $96.2{ }^{\circ} \mathrm{C}(\Delta \mathrm{H}=100.9 \mathrm{~J} / \mathrm{g})$. DSC curves of KMA and $\mathrm{KN}$ cocrystals each have endothermic peaks at $86.1{ }^{\circ} \mathrm{C}$ $(\Delta \mathrm{H}=89.2 \mathrm{~J} / \mathrm{g})$ and $72.4{ }^{\circ} \mathrm{C}(\Delta \mathrm{H}=27.6 \mathrm{~J} / \mathrm{g})$. The two cocrystals showed DSC curves with endothermic peaks which were different from pure ketoprofen and showed similarities with previous study (Wicaksono et al. 2018, 2017).

The FTIR spectra of ketoprofen showed the broad absorption peak at $3300-2400 \mathrm{~cm}^{-1}$ (-OH stretching), $1696 \mathrm{~cm}^{-1}$ (-C=O stretching), $1654 \mathrm{~cm}^{-1} \quad(-\mathrm{C}=\mathrm{O}$ ketone stretching), and 1599 and $1451 \mathrm{~cm}^{-1}$ (aromatic ring $-\mathrm{C}=\mathrm{C}$ - stretching). The malonic acid showed the FTIR spectra with the broad absorption peak at $3400-2400 \mathrm{~cm}^{-1}$ (-OH stretching), and $1700 \mathrm{~cm}^{-1}$ (-C=O stretching). The FTIR spectra of the nicotinamide showed the absorption peaks at $3363 \mathrm{~cm}^{-1} \quad\left(-\mathrm{NH}_{2}\right.$ stretching $), 1676 \mathrm{~cm}^{-1} \quad(-\mathrm{C}=\mathrm{O}$ stretching), $1617 \mathrm{~cm}^{-1}$ (- $\mathrm{NH}_{2}$ deformation), 1573 and 1421 $\mathrm{cm}^{-1}$ (aromatic ring $-\mathrm{C}=\mathrm{C}$ - stretching), and $1397 \mathrm{~cm}^{-1}(-\mathrm{CN}-$ stretching). The FTIR spectra of the ketoprofen, malonic acid, and nicotinamide have similarities with the previous study (Wicaksono et al. 2018, 2017). The FTIR spectra of KMA and KNA cocrystals have absorption peaks that showed shifting compared to the absorption peaks of the pure components. The shifting of the absorption peaks in the FTIR spectra indicated intermolecular interactions in the KMA and KNA cocrystals. In the FTIR spectra, the functional groups that participate in the formation of intermolecular interactions identified by changes in their vibrational modes (Chadha et al. 2014; Diniz et al. 2018). Thus, based on the FTIR spectra, the possibility of the supramolecular interactions that occur in KMA and KNA cocrystals can be estimated.

In the FTIR spectra of KMA cocrystal, the absorption peak of the $-\mathrm{C}=\mathrm{C}-$ stretching of the ketoprofen showed

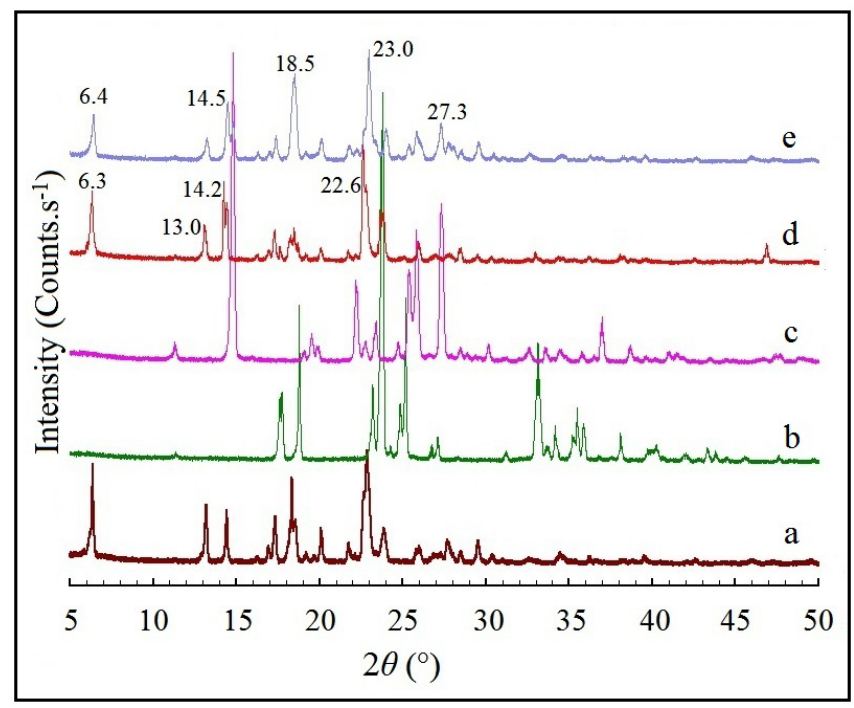

FIGURE 1. PXRD diffractograms of (a) pure ketoprofen, (b) malonic acid, (c) nicotinamide, (d) KMA cocrystal, and (e) KN cocrystal 
shifting from 1451 to $1441 \mathrm{~cm}^{-1}$, while the absorption peak of $-\mathrm{C}=\mathrm{O}$ stretching of the malonic acid showed shifting from 1700 to $1696 \mathrm{~cm}^{-1}$. From the FTIR spectra indicating that the intermolecular interaction in the KMA cocrystal formed from $-\mathrm{C}=\mathrm{C}$ - of ketoprofen with $-\mathrm{C}=\mathrm{O}$ group of malonic acid to create the supramolecular heterosynthon $\mathrm{C}=\mathrm{O}$--- $\pi$ (Diniz et al. 2018; Zhang et al. 2019). The FTIR spectra of KNA indicated shifting of the absorption peak of the $-\mathrm{C}=\mathrm{C}$ - group of ketoprofen from 1451 to $1444 \mathrm{~cm}^{-1}$, also the $-\mathrm{C}=\mathrm{O}$ and $-\mathrm{C}=\mathrm{C}$ - groups of nicotinamide from 1676 to $1695 \mathrm{~cm}^{-1}$ and 1573 to $1576 \mathrm{~cm}^{-1}$, respectively.
The shiftings of the absorption peaks of the groups of ketoprofen and nicotinamide indicated that the KNA cocrystal created from intermolecular interactions of $-\mathrm{C}=\mathrm{C}$ - of the ketoprofen with the $-\mathrm{C}=\mathrm{O}$ and $-\mathrm{C}=\mathrm{C}$ - of the nicotinamide. The $-\mathrm{C}=\mathrm{C}$ - of the ketoprofen and the $-\mathrm{C}=\mathrm{O}$ of the nicotinamide in KNA formed the supramolecular heterosynthons $\mathrm{C}=\mathrm{O}---\pi$, while the $-\mathrm{C}=\mathrm{C}$ - of the ketoprofen and $-\mathrm{C}=\mathrm{C}$ - of the nicotinamide created the intermolecular stacking interaction to formed the supramolecular homosynthons $\pi$--- $\pi$ (Diniz et al. 2018; Zhang et al. 2019).

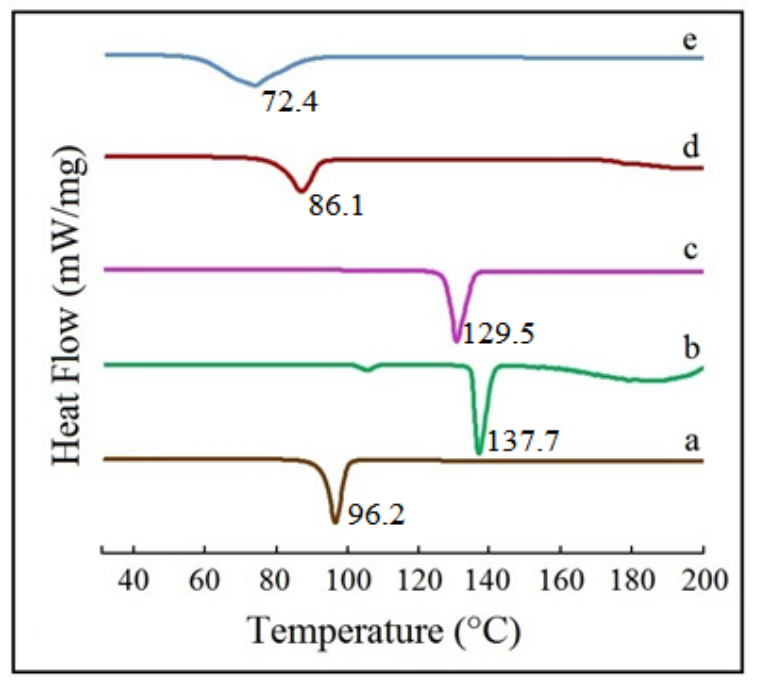

FIGURE 2. DSC curves of (a) pure ketoprofen, (b) malonic acid, (c) nicotinamide, (d) KMA cocrystal, and (e) KN cocrystal

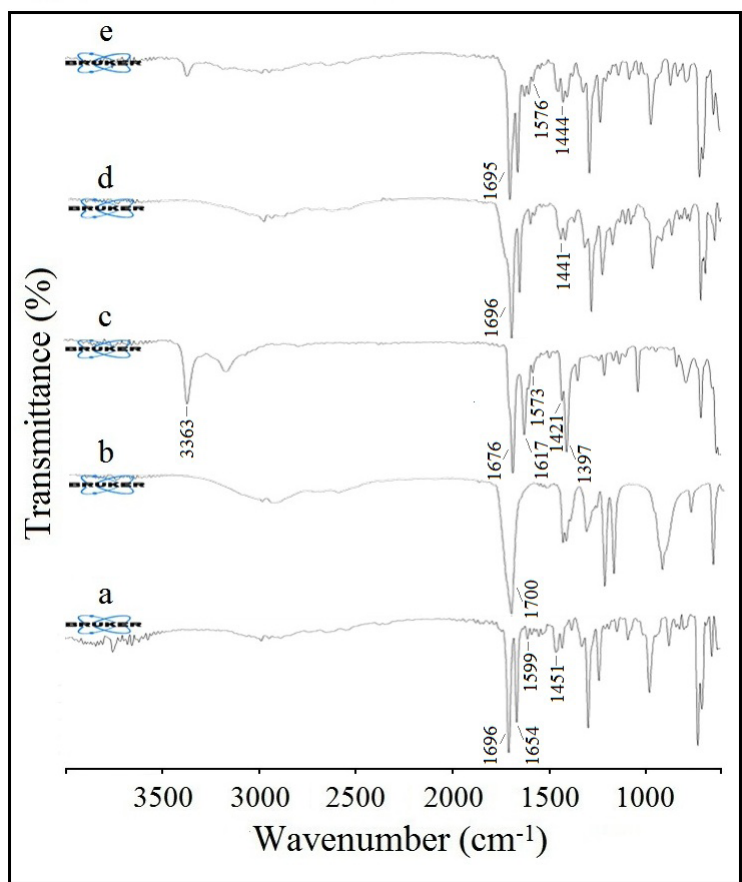

FIGURE 3. FTIR spectra of (a) pure ketoprofen, (b) malonic acid, (c) nicotinamide, (d) KMA cocrystal, and (e) KN cocrystal 


\section{KINETICS PARAMETERS OF THERMAL PROPERTIES}

In the present study, the kinetic parameters ((apparent activation energy $\left(E_{a}\right)$ and pre-exponential factor $(\mathrm{A})$ ) are determined by non-isothermal conditions with multiheating rates. The DSC curves at the different heating rate of pure ketoprofen, KMA cocrystal, and $\mathrm{KN}$ cocrystal were shown in Figure 4. The DSC curves showed a shift of peaks temperature at different heating rates. The peak temperatures $\left(T_{\mathrm{p}}\right)$ of DSC curves corresponding to the melting point at different heating rate were illustrated in Table 1. Based on the Kissinger equation, the result of the plots of $\ln \left(\beta / T_{\mathrm{p}}^{2}\right)$ against $1 / T_{\mathrm{p}}$ is shown in Figure 5. Plotting of the Kissinger analysis gives a straight line, and the activation energies $\mathrm{E}_{\mathrm{a}}$ can be calculated from the slopes $\left(-E_{a} / R\right)$ (Yan et al. 2013). The result of the calculation of kinetic parameters is summarized in Table 2.
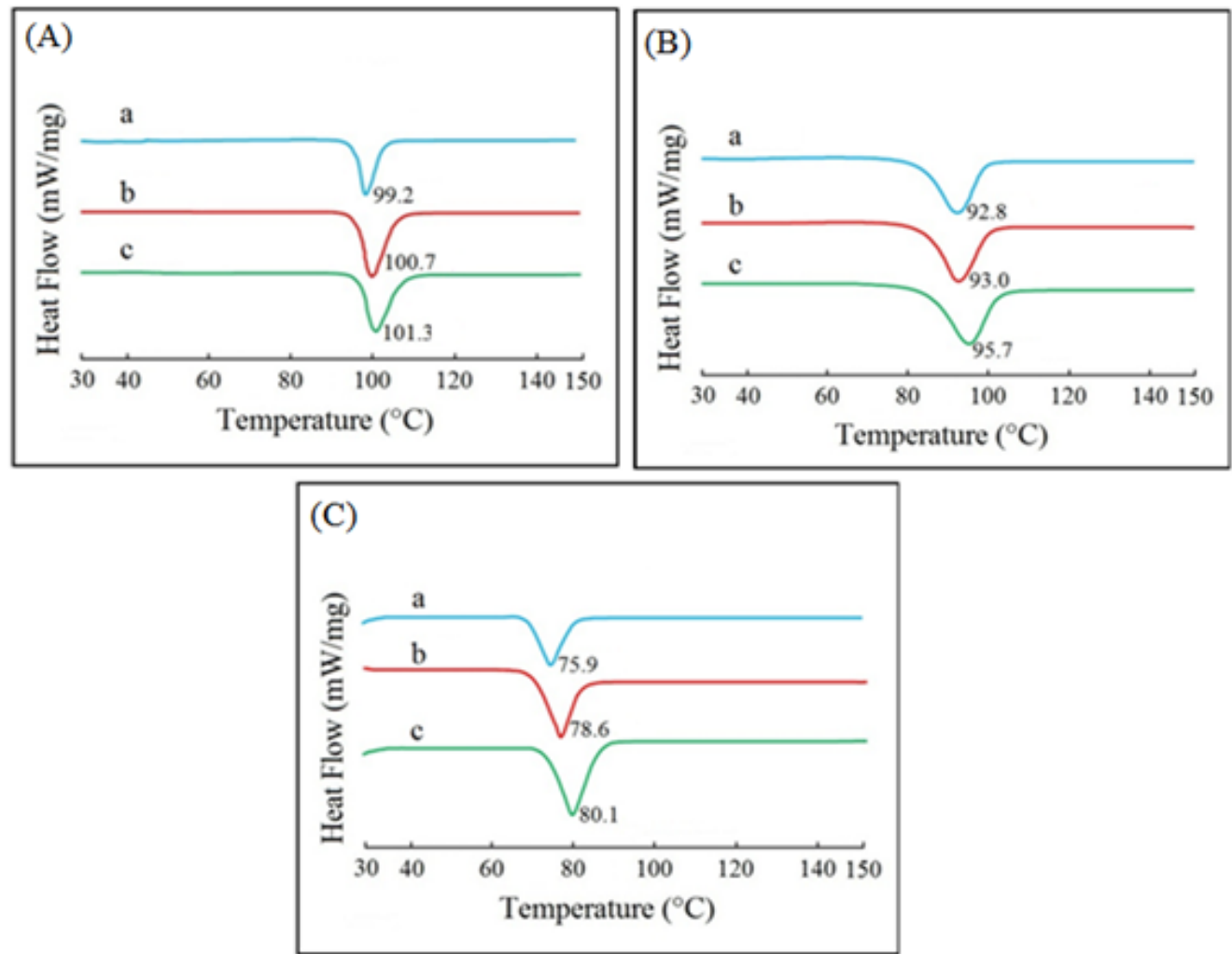

FIGURE 4. DSC curves of (A) pure ketoprofen, (B) KMA cocrystal, and (C) KN cocrystal at a heating rate (a) 15 , (b) 20 , and (c) $25^{\circ} \mathrm{C} / \mathrm{min}$ spectra of (a) pure ketoprofen, (b) malonic acid, (c) nicotinamide, (d) KMA cocrystal, and (e) KN cocrystal

TABLE 1 . The peak temperatures $\left(T_{\mathrm{p}}\right)$ of DSC curves at a different heating rate $(\beta)$

\begin{tabular}{lcc}
\hline Samples & $\beta /\left({ }^{\circ} \mathrm{C} \min ^{-1}\right)$ & $T_{\mathrm{p}}{ }^{\circ} \mathrm{C}$ \\
\hline \multirow{3}{*}{ Pure ketoprofen } & 15 & 99.2 \\
& 20 & 100.7 \\
KMA cocrystal & 25 & 101.3 \\
& 15 & 92.8 \\
KN cocrystal & 20 & 93.0 \\
& 25 & 95.7 \\
& 15 & 75.9 \\
& 20 & 78.6 \\
\hline
\end{tabular}


TABLE 2. The result of the calculation of kinetic parameters

\begin{tabular}{lll}
\hline Samples & $E_{a}\left(\mathrm{~kJ} \mathrm{~mol}^{-1}\right)$ & $A$ \\
\hline Pure ketoprofen & 264.38 & $4.18520 \times 10^{37}$ \\
KMA cocrystal & 384.77 & $4.05634 \times 10^{55}$ \\
KN cocrystal & 116.64 & $4.97766 \times 10^{17}$ \\
\hline
\end{tabular}

The activation energy $\left(E_{a}\right)$ of pure ketoprofen, KMA cocrystal, and KN cocrystal was $264.38,384.77$, and $116.64 \mathrm{~kJ} \mathrm{~mol}^{-1}$, respectively. These showed that KMA cocrystal had the higher apparent activation energy than pure ketoprofen and KN cocrystal. Conversely, $\mathrm{KN}$ cocrystal has the lowest apparent activation energy compared to the other samples. The sample with low apparent activation energy indicates that its thermal stability is relatively poor, so the sample is readily decomposed by temperature (Qi et al. 2014). The results of the determination of the apparent activation energy indicated that KMA cocrystal had the highest thermal stability compared to the pure ketoprofen and KN cocrystal. These results concluded that the KMA cocrystal is not easily decomposed by temperature treatment compared to the pure ketoprofen and KNA cocrystal.
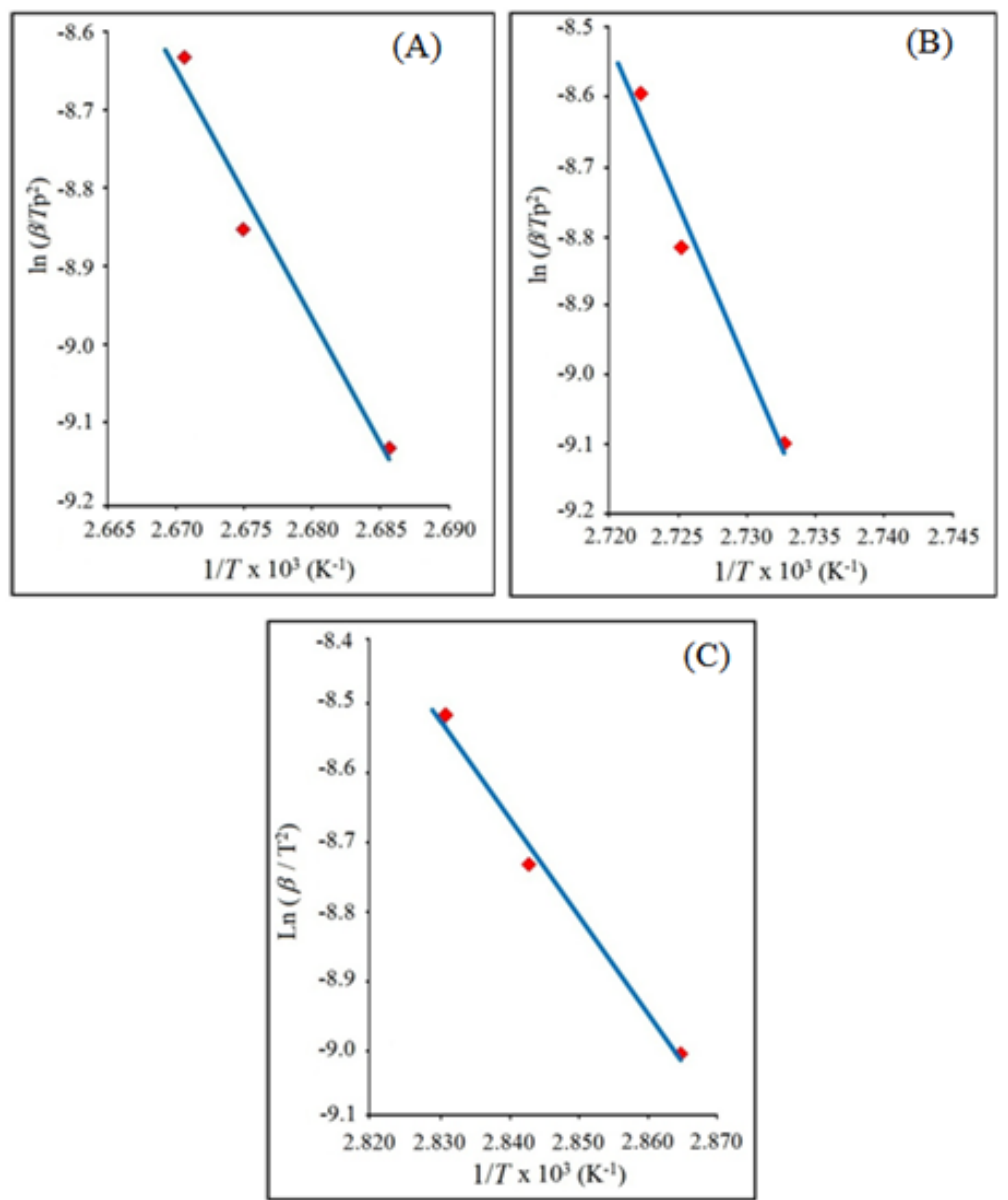

FIGURE 5. FTIR spectra of (a) pure ketoprofen, (b) malonic acid, (c) nicotinamide, (d) KMA cocrystal, and (e) KN cocrystal 


\section{THERMODYNAMIC PROPERTIES}

Based on calculations with the Kessinger equation, the kinetic parameters of thermal properties ((the apparent activation energy (E) and the pre-exponential factor (A)) were obtained. The kinetic parameters are then used to determine the enthalpy of activation $\left(\Delta \mathrm{H}^{*}\right)$, the entropy of activation $\left(\Delta \mathrm{S}^{*}\right)$ and free energy of activation $\left(\Delta \mathrm{G}^{*}\right)$ using Equations (2) - (5) (Boonchom \& Danvirutai 2009; Qi et al. 2014). The result of the calculation of $\Delta H^{*}, \Delta S^{*}$, and $\Delta G^{*}$ of pure ketoprofen, KMA cocrystal, and KN cocrystal were summarized in Table 3 . The values of $\Delta H^{*}, \Delta S^{*}$, and $\Delta G^{*}$ of samples showed a positive value of $\Delta S^{*}$. Based on the activated complex theory (transition theory), the samples indicated a malleable activated complex that leads to a large number of degrees of freedom of rotation and vibration. The value of $\Delta H^{*}$ and $\Delta G^{*}$ are positive, indicating that the formation process of the cocrystals was a non-spontaneous process (Boonchom \& Danvirutai 2009).

TABLE 3. The result of the calculation of thermodynamic parameters

\begin{tabular}{lccc}
\hline Samples & $\begin{array}{c}\Delta H^{*} \\
\left(\mathrm{~kJ} \mathrm{~mol}^{-1}\right)\end{array}$ & $\begin{array}{c}\Delta S^{*} \\
\left(\mathrm{~J} \mathrm{~K}^{-1} \mathrm{~mol}^{-1}\right)\end{array}$ & $\begin{array}{c}\Delta G^{*} \\
\left(\mathrm{~kJ} \mathrm{~mol}^{-1}\right)\end{array}$ \\
\hline Pure ketoprofen & 261.31 & 465.22 & 89.53 \\
KMA cocrystal & 381.78 & 809.77 & 90.87 \\
KN cocrystal & 113.76 & 84.34 & 84.62 \\
\hline
\end{tabular}

A solid form of material in the environment under melting temperatures was the most thermodynamically stable as it has lower free energy than the liquid form (McClements 2012). Free energy of activation $\left(\Delta G^{*}\right)$ was associated with nuclei formation of crystal and must be overcome before the transition process of liquid to solid form. Based on this, the free energy of activation was proportional to the crystal lattice energy, which was the energy that binds the crystalline constituent components of the crystalline solid (Kuleshova et al. 2013; McClements 2012). The results of the determination of free energy of activation $\left(\Delta G^{*}\right)$ showed that the free energy of activation $\left(\Delta G^{*}\right)$ of KMA cocrystal was greater than $\mathrm{KN}$ cocrystal. These results indicated that the KMA cocrystal was formed from the components by the energy of crystal lattice which higher than the energy of crystal lattice of $\mathrm{KN}$ cocrystal.

\section{CONCLUSION}

The Kissinger protocol successfully determined the thermal behavior of KMA and KN cocrystals. The thermodynamic parameters of cocrystals were determined based on the kinetic parameters data using the general thermodynamic equation. The KMA cocrystal had the highest apparent activation energy compared to pure ketoprofen and KN cocrystal indicating the highest thermal stability. Thermodynamic parameters evaluation found the ketoprofen cocrystals to possess a positive value of $\Delta \mathrm{S}^{*}$ which represented a non-spontaneous process formation of the cocrystals. The free energy of activation $\left(\Delta \mathrm{G}^{*}\right)$ of KMA cocrystal showed a greater value than $\mathrm{KN}$ cocrystal indicating the formation of the crystal lattice of KMA cocrystal involved higher binding energy.

\section{ACKNOWLEDGEMENTS}

This research is supported by the Ministry of Research, Technology, and Higher Education of the Republic of Indonesia (Doctoral dissertation research grant, contract number 1867/UN25.3.1/LT/2017).

\section{REFERENCES}

Boonchom, B. \& Danvirutai, C. 2009. Kinetics and thermodynamics of thermal decomposition of synthetic $\mathrm{AlPO}_{4} \cdot 2 \mathrm{H}_{2} \mathrm{O}$. Journal of Thermal Analysis and Calorimetry 98(3): 771-777.

Chadha, R., Bhandari, S., Haneef, J., Khullar, S. \& Mandal, S. 2014. Cocrystals of telmisartan: Characterization, structure elucidation, in vivo and toxicity studies. CrystEngComm 16: 8375-8389.

Chow, S.F., Chen, M., Shi, L., Chow, A.H.L. \& Sun, C.C. 2012. Simultaneously improving the mechanical properties, dissolution performance, and hygroscopicity of ibuprofen and flurbiprofen by cocrystallization with nicotinamide. Pharmaceutical Research 29(7): 1854-1865. 
Diniz, L.F., Souza, M.S., Carvalho, Jr. P.S., da Silva C.C.P., D'Vries, R.F. \& Ellena, J. 2018. Novel isoniazid cocrystals with aromatic carboxylic acids: Crystal engineering, spectroscopy and thermochemical investigations. Journal of Molecular Structure 1153: 58-68.

Evora, A.O.L., Castro, R.A.E., Maria, T.M.R., Silva, M.R., Ter Horst, J.H., Canotilho, J. \& Eusebio, M.E.S. 2014. A thermodynamic based approach on the investigation of a diflunisal pharmaceutical co-crystal with improved intrinsic dissolution rate. International Journal of Pharmaceutics 466(1-2): 68-75.

Goud, N.R., Gangavaram, S., Suresh, K., Pal, S., Manjunatha, S.G., Nambiar, S. \& Nangia, A. 2012. Novel furosemide cocrystals and selection of high solubility drug forms. ¡ournal of Pharmaceutical Sciences 101(2): 664-680.

Kuleshova, L.N., Hofmann, D.W.M. \& Boese, R. 2013. Lattice energy calculation - a quick tool for screening of cocrystals and estimation of relative solubility. Case of flavonoids. Chemical Physics Letters 564: 26-32.

Liu, X., Lu, M., Guo, Z., Huang, L., Feng, X. \& Wu, C. 2012. Improving the chemical stability of amorphous solid dispersion with cocrystal technique by hot melt extrusion. Pharmaceutical Research 29(3): 806-817.

Liu, W., Dang, L. \& Wei, H. 2013. Thermal, phase transition, and thermal kinetics studies of carbamazepine. Journal of Thermal Analysis and Calorimetry 111(3): 1999-2004.

Ma, P., Zhang, L., Zhu, S.G. \& Chen, H.H. 2012. Synthesis, structural investigation, thermal decomposition, and properties of a cocrystal energetic perchlorate amine salt. Combustion, Explosion, and Shock Waves 48(4): 483-487.

Masuda, T., Yoshihashi, Y., Yonemochi, E., Fujii, K., Uekusa, H. \& Terada, K. 2012. Cocrystallization and amorphization induced by drug-excipient interaction improves the physical properties of acyclovir. International Journal of Pharmaceutics 422(1-2): 160-169.

McClements, D.J. 2012. Crystals and crystallization in oil-inwater emulsions: Implications for emulsion-based delivery systems. Advances in Colloid and Interface Science 174: $1-30$.

Perpetuo, G.L., Chierice, G.O., Ferreira, L.T., Fraga-Silva, T.F.C., Venturini, J., Arruda, M.S.P., Bannach, G. \& Castro, R.A.E. 2017. A combined approach using differential scanning calorimetry with polarized light thermomicroscopy in the investigation of ketoprofen and nicotinamide cocrystal. Thermochimica Acta 651: 1-10.

Pindelska, E., Sokal, A. \& Kolodziejski, W. 2017. Pharmaceutical cocrystals, salts and polymorphs: Advanced characterization techniques. Advanced Drug Delivery Reviews 117: 111-146.

Qi, Z., Zhang, D., Chen, F., Miao, J. \& Ren, B. 2014. Thermal decomposition and non- isothermal decomposition kinetics of carbamazepine. Russian Journal of Physical Chemistry A 88(13): 2308-2313.

Shohin, I.E., Kulinich, J.I., Ramenskaya, G.V., Abrahamsson, B., Kopp, S., Langguth, P., Polli, J.E., Shah, V.P., Groot, D.W., Barends, D.M. \& Dressman, J.B. 2012. Biowaiver monographs for immediate-release solid oral dosage forms: Ketoprofen. Journal of Pharmaceutical Sciences 101(10): 3593-3603.
Sowa, M., Slepokura, K. \& Matczak-Jon, E. 2014. Solid-state characterization and solubility of a genistein-caffeine cocrystal. Journal of Molecular Structure 1076: 80-88.

Srivastava, A., Chandel, N. \& Mehta, N. 2017. Calorimetric studies of crystallization for multi-component glasses of $\mathrm{Se}-\mathrm{Te}-\mathrm{Sn}-\mathrm{Ag}$ (STSA) system using model-free and modelfitting non-isothermal methods. Journal of Thermal Analysis and Calorimetry 128(2): 907-914.

Teoh, X.Y., Mahyuddin, F.N., Ahmad, W. \& Chan, S.Y. 2020. Formulation strategy of nitrofurantoin: Co-crystal or solid dispersion? Pharmaceutical Development and Technology 25(2): 245-251.

Tita, D., Fulias, A. \& Tita, B. 2011. Thermal stability of ketoprofen - active substance and tablets. Journal of Thermal Analysis and Calorimetry 105(2): 501-508.

Tita, B., Fulia, A., Bandur, G., Rusu, G. \& Tita, D. 2010. Thermal stability of ibuprofen. Kinetic study under non-isothermal conditions. Revue Roumaine Chimie 55(9): 553-558.

Vaghela, R., Kulkarni, P.K., Hani, U., Varma, V.N.S.K. \& Abhay, R. 2014. Enhancing aqueous solubility of ketoprofen by fusion technique using suitable co-formers. Current Drug Therapy 9(3): 199-207.

Wang, J.R., Yu, X., Zhou, C., Lin, Y., Chen, C., Pan, G. \& Mei, X. 2015. Improving the dissolution and bioavailability of 6-mercaptopurine via co-crystallization with isonicotinamide. Bioorganic \& Medicinal Chemistry Letters 25(5): 1036-1039.

Wicaksono, Y., Setyawan, D. \& Siswandono, S. 2018. Multicomponent crystallization of ketoprofennicotinamide for improving the solubility and dissolution rate. Chemistry Journal of Moldova 13(2): 74-81.

Wicaksono, Y., Setyawan, D. \& Siswandono, S. 2017. Formation of ketoprofen-malonic acid cocrystal by solvent evaporation method. Indonesian Journal of Chemistry 17(2): 161-166.

Yan, Q.L., Zeman, S., Elbeih, A., Song, Z.W. \& Malek, J. 2013. The effect of crystal structure on the thermal reactivity of CL20 and its $\mathrm{C} 4$ bonded explosives (I): Thermodynamic properties and decomposition kinetics. Journal of Thermal Analysis and Calorimetry 112(2): 823-836.

Yang, X., Wang, J., Song, H. \& Zou, W. 2016. Thermal properties and solubility of methyl $\alpha$-D-glucopyranoside in methanol at different temperatures. Fluid Phase Equilibria 409: 417424.

Yuliandra, Y., Zaini, E., Syofyan, S., Pratiwi, W., Putri, L.N., Pratiwi, Y.S. \& Arifin, H. 2018. Cocrystal of ibuprofennicotinamide: Solid-state characterization and in vivo analgesic activity evaluation. Scientia Pharmaceutica 86(2): 23-33.

Zhang, Y., Yan, C.M., Chen, C., Zhao, X.Q., Li, T. \& Sun, B.W. 2019. Three new cocrystals derived from liquid pyrazine spices: x-ray structures and Hirshfeld surface analyses. Research on Chemical Intermediates 45(11): 5745-5760.

Yudi Wicaksono*

Department of Pharmaceutics

Faculty of Pharmacy

University of Jember

68121 Jember

Indonesia 
Dwi Setyawan

Department of Pharmaceutics

Faculty of Pharmacy

Airlangga University

60286 Surabaya

Indonesia

Ari Satia Nugraha

Drug Utilisation and Discovery Research Group

Faculty of Pharmacy

University of Jember

68121 Jember

Indonesia

Siswandono

Department of Pharmaceutical Chemistry

Faculty of Pharmacy

Airlangga University

60286 Surabaya

Indonesia
Yudi Wicaksono* \& Ari Satia Nugraha

Center for Development of Advanced Science and Technology

University of Jember

68121 Jember

Indonesia

*Corresponding author; email: yudi.farmasi@unej.ac.id

Received: 30 November 2019

Accepted: 25 May 2020 